\title{
KNOWLEDGE PRODUCTION METHODS IN HUMAN RIGHTS RESEARCH: CONSTRAINTS AND OPPORTUNITIES FOR THE PROMOTION OF AN INTERDISCIPLINARY APPROACH ${ }^{1}$
}

\author{
CRISTINA DE LA CRUZ-AYUSO ${ }^{2}$
}

\begin{abstract}
This article asks about the current modes of production in human rights research and how they are (or may be) determined by the structures where that knowledge is generated. These questions will be answered by looking at the results of a preliminary study on the reception and subsequent institutionalisation of studies on human rights in stable structures that are dedicated to their research, training and dissemination in Spanish universities. The starting hypothesis is that this institutionalisation causes conceptual, epistemological and methodological biases in the rationales for knowledge construction in the field of human rights that determine and hinder the interdisciplinary approach demanded by its study. Interdisciplinarity has become a dominant aspect of human rights research. The question about how this feature is articulated and who articulates it in the academic institutional framework is pertinent in a field of knowledge that cannot avoid asymmetries in the production and circulation of knowledge. The results show that human rights research has been mainly institutionalised in stable university structures in Spain within the field of legal sciences, with a clear predominance of the area of the Philosophy of Law. It can be concluded that this has been conditioned by the reception and subsequent development of the study of human rights in Spain. While it has been found that the line developed by these centres and research groups has been consolidated and recognised, it can also be confirmed that their modes of knowledge production do not match the rationale of interdisciplinary research. These limitations are not just endogenous. There are some features of Spanish institutional R\&D\&i culture that make interdisciplinary research on human rights difficult.
\end{abstract}

Keywords: human rights, epistemology, knowledge production, interdisciplinary, research, institutionalisation, academic structures.

Summary: I. HOW DO WE COME TO UNDERSTAND WHAT WE NEED TO KNOW ABOUT HUMAN RIGHTS? II. WHAT ARE THE MODES OF KNOWLEDGE PRODUCTION IN HUMAN RIGHTS RESEARCH? III. HOW DO (OR CAN) THE STRUCTURES WHERE KNOWLEDGE ABOUT HUMAN RIGHTS IS GENERATED INFLUENCE ITS MODES OF PRODUCTION? HOW DO (OR CAN) THESE STRUCTURES RELATE TO THE MODES OF PRODUCTION OF KNOWLEDGE ABOUT HUMAN RIGHTS? III.1. A brief mapping of the institutional structures for human rights research. IV. LIMITATIONS AND OPPORTUNITIES FOR THE PROMOTION OF AN INTERDISCIPLINARY APPROACH IN HUMAN RIGHTS RESEARCH. REFERENCES.

\footnotetext{
${ }^{1}$ The research leading to this publication was funded by the Spanish Ministry of Economy as part of the research project entitled 'Complex inequality in plural societies: Indicators for public policies' [DER201677711-P] and by the Basque government through the financial support granted to the activities of research groups in the Basque university system (IT1224-19).

${ }_{2}^{2}$ Pedro Arrupe Human Rights Institute, University of Deusto, Spain (delacruz@ deusto.es).
} 


\section{HOW DO WE COME TO UNDERSTAND WHAT WE NEED TO KNOW ABOUT HUMAN RIGHTS?}

How should human rights research be conducted? This question has not attracted much interest among the academic community, nor is it one of the usual or recurring themes of human rights epistemology (Gerwith, 1984; Claude, 2002). Debate on this area has mainly focused on its interdisciplinary nature (Hafner-Burton, 2013; Klein, 1990; $2010^{\mathrm{a}}$; Gibbons et al, 2010), but it has barely delved into the rationales and modes of knowledge production that characterise human rights research (Barry et al., 2008). Consequently, academia has not reflected on the potential conceptual, epistemological and methodological biases involved in this type of research.

Is the usual mode of knowledge production in the field of human rights interdisciplinary in nature? This question may seem irrelevant considering the strong acceptance of the idea that interdisciplinarity ${ }^{3}$ is an inherent feature in the type of research that characterises the study of human rights (Freeman, 2011; Chandramohan and Fallows, 2009). Why? Because we need to know many different things about human rights. Appropriately addressing the challenges involved requires crossing the borders of the different disciplines that deal with human rights and working in environments which are open to interdisciplinary collaboration. So far, so obvious. However, ascertaining that there is an epistemological need in human rights research should not lead us to think that this is the usual mode of knowledge production. We need the study of human rights to be interdisciplinary, but is it really?

Human rights are at the centre of research in many fields such as law, philosophy, political science, anthropology and history, to name just a few. They are also at the core of the activities carried out by many organisations, social movements and institutions that are committed to their defence and responsible for their implementation. There is abundant research on issues directly related to human rights that has been conducted by groups composed of researchers from different areas. It would be unfair, therefore, not to recognise the collaborative efforts or dynamics that often take place in some contexts that deservedly place human rights studies at the heart of an interdisciplinary approach, both on a theoretical and a practical level. However, this tradition has been developed without an in-depth analysis of the demands and implications that the interdisciplinary nature of the study of human rights has on the processes of knowledge production. We usually resort to the various disciplines to take from them what we need to know about human

\footnotetext{
${ }^{3}$ In this study the term interdisciplinarity will be used, but without delving into the wider debate about the scope and use of terms related to it, such as multidisciplinarity, pluridisciplinarity and transdisciplinarity. The choice of one or the other depends on each school (Hirsch-Hardon et al., 2008; Haight and Bidwell, 2016; Huutoniemi et al., 2010). Interdisciplinarity is often used to refer to a type of research that integrates perspectives, methodologies, concepts and/or techniques from two or more disciplines, or areas of specialised knowledge, in order to solve certain complex problems (Klein 2008; 201 Jacobs and Frickel, 2009). 'This interaction may range from simply communication of ideas to the mutual integration of organising concepts, methodology, procedures, epistemology, terminology, data and organisation of research and education in a fairly large field. An interdisciplinary group consists of people trained in different fields of knowledge (disciplines) with different concepts, methods, data and terms' (Apostel et al., 23-24).
} 
rights. Consequently, the way we come to understand them and the methods we use to study them are those that are epistemologically accepted and methodologically agreed upon within each individual discipline.

Each of the disciplines stands as a body of knowledge and a set of methods, theories and concepts shared by a community that has developed its own legitimising systems and is constituted around formal networks of practice, such as, for example, each discipline's scientific associations or scientific publications (Ziman, 2000). ${ }^{4}$ All of this has a crucial role in shaping knowledge. The objective of interdisciplinary work is the construction or production of knowledge from a multiple perspective to provide solutions to complex problems. But its operating rationale necessarily involves the disciplines that participate in a specific study using their own epistemological and methodological frameworks. In the field of human rights research, this is often the way of working in academic research groups. Teams are often comprised of researchers from different traditions and specialisms that come together to expand knowledge and address a specific research problem related to human rights. These researchers can only make their contributions by using the tools of their respective disciplines. The outputs tend to be a sum of concepts, not always well articulated, in which some stand out more than others depending on the way in which the data and the results of a study have been processed, discussed and interpreted.

However, interdiscipline is not constructed as a discursive mix of different disciplinary approaches (Klein 201 Langford, 2016; Jacobs and Frickel, 2009). It is constructed from a common approach to human rights as a concrete object of study. Therefore, a multidisciplinary work dynamic does not always allow for a suitable resolution of the problems that human rights face in practice. The question demands finding a way of articulating the language, methods and corpus of each discipline (Frodeman et al, 2010; Holley, 2009). This is what properly characterises an interdisciplinary approach; but in practice it is both complex and unnatural (Geertz, 1980).

The use of interdisciplinarity faces several problems related to the development of disciplines that go beyond the usual theoretical communication barriers that exist or may exist between them. Interdisciplinarity clashes with the identity and recognition of

\footnotetext{
${ }^{4}$ The large number of existing areas of knowledge was classified into a UNESCO Nomenclature for Fields of Science and Technology in 1973 and 1974 by the UNESCO Division of Science Policy and the Division of Statistics on Science and Technology and adopted by the now-defunct Scientific and Technical Research Advisory Commission in Spain (Comisión Asesora de Investigación Científica y Técnica). This classification was adopted by the Ministry of Science and Technology in Spain in 1983, by virtue of the Resolution of 23 September 1983 (BOE 14 October). In this nomenclature Human Rights appeared as a subdiscipline (590601) dedicated to the activities of a discipline, Political Sociology (5906), belonging to the field of knowledge of Political Science.

[Source: Ministry of Science, Innovation and Universities of the Government of Spain (Ministerio de Ciencia, Innovación y Universidades del Gobierno de España). Available at: http://www.ciencia.gob.es/portal/site/MICINN/menuitem.8ce192e94ba842bea3bc811001432ea0/?vgnext oid=363ac9487fb02210VgnVCM1000001d04140aRCRD\&vgnextchannel=28fb282978ea0210VgnVCM 1000001034e20aRCRD. Last accessed on 10 May 2019].
} 
the autonomy of each discipline (Frodeman, 2014; Klein, 2010b, Gumport and Snydman, 2002; Hafner-Burton, 2013). And it is faced with problems that cannot be ignored, such as hegemonic approaches or approaches that delegitimise other knowledge; analytical fragmentation; inertia in the established research system which does not allow for or promote the flexibility required for interdisciplinarity to be appropriately applied; and the biased institutionalisation of human rights research in academic structures in which the legal sciences still clearly and unquestionably predominate (Forsythe, 2017).

This article asks about the current modes of production in human rights research and how they are (or may be) determined by the structures where that knowledge is generated. These questions will be answered based on the results of a preliminary study on the reception and subsequent institutionalisation of studies on human rights in stable structures that are dedicated to their research, training and dissemination in Spanish universities. The starting hypothesis is that this institutionalisation causes conceptual, epistemological and methodological biases in the rationales for knowledge construction in the field of human rights that determine and hinder the interdisciplinary approach demanded by its study. Interdisciplinarity has become a dominant aspect of human rights research. The question about how this feature is articulated and who articulates it in the academic institutional framework is pertinent in a field of knowledge that cannot avoid asymmetries in the production and circulation of knowledge.

\section{WHAT ARE THE MODES OF KNOWLEDGE PRODUCTION IN HUMAN RIGHTS RESEARCH?}

This question hides an aspiration that cannot really be satisfied due to the wide range of disciplines and specialisms that currently contribute to the study and implementation of human rights. And yet, addressing this question is not part of the objectives of this study. It is used here for its narrative eloquence, since it suggests the tensions inherent in human rights research without a need for over-explanations. These tensions constitute an important aspect of the problem linked to the limitations of the interdisciplinary approach to their study.

There are different and varying ways of producing knowledge in human rights research. Law, philosophy, history, anthropology and political science, among others, are disciplines that have contributed and expanded normative, conceptual, historiographic, empirical and discursive knowledge about human rights. In general, it can be said that human rights are a useful object of study and category of analysis for many disciplines, and that their interaction makes them more effective when it comes to finding thorough and correct solutions to the problems it poses (Freeman, 2011). However, the dialogue and collaboration between them has revealed, on the one hand, a high level of disagreements and, on the other, serious epistemological and methodological difficulties in resolving them.

Human rights have been conceived on the basis of two separable, independent and totally detached components. This makes any attempts at interdisciplinarity in their study difficult. These components are the theory of human rights, in which a battle of ideas has 
been fought about their nature and scope; and the method to apply them and make them effective, mainly in the most vulnerable contexts. ${ }^{5}$ The truth is that the different approaches to some specific human rights issues by each specialist discipline have generated tensions that are difficult to overcome.

The nature of the concept of human rights and the 'crisis' in its foundations has brought with it an abundant and controversial literature to follow up on one of the most disputed debates between philosophy, political science and law, characterised by having 'more points of divergence than points in common' (Harrison, 2005, p. 35). The words with which Bobbio began his study 'Present and future of human rights' are a good example of the controversial nature of this debate and its scope:

Three years ago, in 1964, at the conference organised by the 'Institut International de Philosophie' on 'The principle of human rights', I stated categorically at the end of my paper (...) that the serious problem facing our times with respect to human rights was not one of finding fundamental principles for human rights, but that of protecting them. Since then I have had no reason to change my mind. That sentence, which could have been controversial if it had been addressed to an audience of philosophers, when uttered before a meeting of predominantly legal scholars (...) served as an almost compulsory introduction (Bobbio, 1991, pp. 63-64).

Another recurring debate that has highlighted these tensions has been the polarisation between theoretical and practical problems in human rights studies (Donnelly, 2003). This has led to barriers not only between disciplines, but also between researchers and human rights practitioners. This has been especially significant, for example, in the different anthropological approaches to the field of human rights (Downing and Kushner, 1988; Messer, 1993) which previously had resulted in a broad and sustained discussion on the role of this discipline in human rights research. The theoretical debates on universalism and relativism initially monopolised the interest of anthropology in human rights in the 1980s, but soon gave way to strong criticism of the restrictions imposed on the theoretical and political potential of anthropology for studying and addressing human rights violations.

The debate on universalism and relativism was gradually put aside because it was unproductive at a time and in a context in which human rights research was faced with various practical dilemmas and its discourse was expanding worldwide. It was at this time of epistemic and practical self-reflection when anthropological research on human rights was at its height and new conceptualisations, interactions, processes, dynamics and participatory and activist methodologies were incorporated into it. This questioning forced many of the basic precepts of anthropology to be redefined. They came mainly from feminist theory (Haraway, 1988), critical race theory, studies on subaltern groups (Spivak, 1988) and postmodern and postcolonial theories (Harrinson, 2005). All of them,

\footnotetext{
${ }^{5}$ Human rights have generally been thought of as theory. They have hardly ever been considered to be a method, except for pre-eminence that the rights-based approach to cooperation and development once had (with appropriate caution about its underlying predominant vision). Available at: http://hrbaportal.org/thehuman-rights-based-approach-to-development-cooperation-towards-a-common-understanding-among-unagencies [Accessed on 10 May 2019].
} 
from different perspectives, questioned the recognition of anthropology as a social science and its validity to provide some definitive truth about human cultures. Scientific objectivity was described as an impossible and even insidious goal because of the political effects that anthropological research had on 'others'. These claims appealed to the need to decolonise the relationship between researcher and researched, and to work towards an emancipation-oriented anthropology (Gordon, 1991).

The contributions of these critical theories to the effects of knowledge production on human rights violations, marginalisation and discrimination centred their criticisms on the excessive legalism that seems to characterise and reach a saturation point in human rights research. Some studies have indicated that the pre-eminence of the legal approach to human rights makes it difficult to deliberate on and fight for social justice and human rights, because it is carried out within a reduced legal framework and closes the door to more radical political demands (Brown, 1995). Moreover, it has also been argued that the regulatory and normative discourse of human rights is part of the engine of capitalism and promotes the normalisation of certain power relations that actually serve (or may serve) to reinforce oppressive structures and discourses (Ignatieff, 2001; Brown and Haley, 2002, p. 24).

The demand for a critical review of the prevailing, law-governed view in institutions linked to human rights research has in turn been strongly countered by arguments within the legal disciplines. These have brought attention to the global decline of human rights as regulatory frameworks, and the implications that this has for their protection. Human rights have been losing their character of legally binding rules initially for States, but also for groups and individuals. In this context, it has been argued, human rights are longer standards of behaviour that critically assess the quality of government, democracy and social relations. They are rendered invisible or silent and are presented as a mere desideratum; as target values or objectives that would be desirable to achieve, but see their implementation and enjoyment ultimately hindered. We are witnessing a setback and weakening of the normative force of human rights and a process to criminalise their defence. It seems urgent, therefore, to make progress in the legal dimension of human rights research. This debate clearly outlines the obstacles that human rights research faces for interrelating with other hegemonic areas of knowledge and with highly questioned epistemological positions. But it also acknowledges a dialogue that highlights the need to strengthen a research methodology on human rights that combines different critical approaches and takes into account the impact and effects of their modes of production and reproduction of knowledge which, on occasion, serve limited, short-term objectives and goals.

One of the major lessons from Freeman's classic study on the interdisciplinary nature of human rights (Freeman, 2011, pp. 91-93) is the one that points to the apparent correlation between the interest that a discipline has in human rights and a specific historical need. This trend was well illustrated by events in the 1970s: human rights became recognised in international law and in international relations, in what came to be called the 'last utopia' (Moyn, 2010). And it was at this point that they began to be taken seriously as an object of study by different disciplines, including social sciences. The 
creation of the Human Rights Quarterly journal in 1979 was important for the development of this area and for opening it up to other disciplines, as it became widely recognised as the leading journal in the field of human rights. In that decade, studies that have become classics were published, since they showed the growing prominence and increasing number of studies on human rights by other non-legal disciplines such as political science, sociology, historiography and anthropology. ${ }^{6}$ Human rights began to play an important part in the work and the analytical agenda of these disciplines' main international networks and associations. And although the study of human rights continued to be dominated by the law (a hegemony that has not been seriously challenged), there was some internal critical questioning that originated in the 1970s and 1980s and cast doubt on that hegemonic vision of human rights.

Freeman (2011) called for research to be conducted into the social, political and economic constraints that led the analysis of human rights to play such a prominent role in many disciplines. It is true that they did not interact with each other, but they welcomed human rights to respond to specific historical problems. Crucially, they were able to complement approaches within the disciplines that had traditionally studied human rights, philosophy and law, which were insufficient.

The analysis of the genesis and evolution of human rights research has allowed intrinsic intra- and inter-disciplinary tensions to emerge. On the one hand, interdisciplinary research on human rights seems to require a connection of theoretical knowledge with an experience-based practice that, in many cases, appears under a narrative hegemonised by the formalism of legal discourse. On the other hand, knowledge of human rights seems to be preferentially conveyed through conceptual and practical resolutions of legal knowledge, to the detriment of those rights that could be provided by using an emancipatory or a critical approach.

How can we move forward? Undoubtedly, it is necessary to find a balance between the need for disciplinary specialisation and interdisciplinarity, recognising both the benefits derived from one and the other and the disadvantages and threats inherent in the polarised areas in the study of human rights. Human rights are articulated on a legal basis that enables and guarantees their implementation. This is indisputable. But it is also true that human rights are not reduced only to jurisprudence, laws, rules or legislation. Nor to philosophy. The understanding of human rights needs to be complemented by the contribution of other disciplines, because the interaction among them is the most effective way of finding solutions to the problems posed by research in the field of human rights. The interaction between politics and the law offers real and effective guarantees for the protection of human rights. The interaction between anthropology and public international law relates human rights to everyday life, allows the distribution of human rights, their meaning and the effect they have on people to be identified. The interaction between economics and philosophy makes it possible to provide a very specific answer

\footnotetext{
${ }^{6}$ Without any attempt at completeness, these publications are particularly remarkable, by way of example: Claude, RP (ed.) (1976). Comparative Human Rights. Baltimore: Johns Hopkins University Press; Forsythe, D. P. (1989). Human Rights and World Politics. Lincoln, NE: University of Nebraska Press; Vincent, R.J. (1986). Human Rights and International Relations. Cambridge: Cambridge University Press.
} 
to the question of who should enforce some human rights (such as social and economic rights) and how to do so.

The European Commission identified interdisciplinarity as one of its fundamental challenges for the ERA (European Research Area) and the 2020 Horizon Programme (European Commission, 2015). The reason repeatedly adduced was the need for science to be able to address complex problems quickly and effectively across disciplinary boundaries. However, how to implement interdisciplinarity does not seem to be easy. This was also admitted by the European Commission in its report:

While there are plenty of data, insights and lessons on directed research programs and organized research units at universities, we have but next to no empirical evidence on how to best stage interdisciplinarity, about the added value it may produce, and what it may take universities and research organizations to effectively cross narrow disciplinary boundaries, perspectives, and interests. The ironic bottom line is that we need both more interdisciplinarity, and more organizational experiments, to advance it, and to learn more about what is conducive to it, what works and what does not (European Commission, 2015, p. 4).

Obviously, it is not merely a question of applying methods, concepts, approaches or theories of different disciplines that offer a rich and varied mosaic of views around the same problem. Not every approach is valid when it comes to solving or dealing with a problem, nor is everything useful and necessary. Interdisciplinarity understood as a methodological tool for human rights research does not need to bring disciplines together in order to be effective. It requires, on the contrary, knowledge of how these disciplines can interact with each other, which demands, first, that each discipline take the others seriously. In the theory of human rights research, this seems to be well understood and accepted, to the extent that no one questions its interdisciplinary nature. And yet in practice this is an unsolved problem, even though no effort has been spared to move in this direction. The lessons learnt often provide disappointing examples of research results or publications in which several disciplines have been involved, each making its own contribution and adopting its specific perspective; but it is evident that there has been little or no interaction between them.

What are the obstacles for interdisciplinarity to be possible, effective and real in human rights research? Research on the interdisciplinary construction of knowledge has focused mainly on clarifying what this term means. There is vast literature on the different existing angles and the tensions it entails (Lattuca, 2001; Repko et al., 2011; Frodeman, 2014). The field of human rights does not escape these tensions and obstacles either.

As this section has shown, some obstacles are the different ways of producing knowledge are an obstacle and the difficulties for between the different disciplines involved in the study of human rights to interact between them. There are methodological proposals that can help disciplines move in this direction, which offer a comprehensive and systematic presentation of the interdisciplinary research process (Repko and Szostak, 2017). However, these methodological approaches may not be sufficient to overcome these obstacles if there is really a dominant vision in the institutional environments linked 
to human rights research. This paper asks about the role that structures play in these processes and the importance they have or may have for their legitimisation. By investigating the impact that the institutional structures involved in knowledge production have, some evidence can be obtained about how these obstacles originate and discuss whether they in fact address the challenge of making interdisciplinarity possible.

\section{HOW DO (OR CAN) THE STRUCTURES WHERE KNOWLEDGE ABOUT HUMAN RIGHTS IS GENERATED INFLUENCE ITS MODES OF PRODUCTION? WHAT DO (OR CAN) THESE STRUCTURES RELATE TO THE MODES OF PRODUCTION OF KNOWLEDGE ABOUT HUMAN RIGHTS?}

The analysis of the formal structures of academic research on human rights has not been sufficiently addressed in justifying the role they have in the interdisciplinary construction of knowledge of this area. However, it is precisely those structures, along with their identity and the practices they engage in, that make up the features and categories of that knowledge. These structures are institutional scenarios that are not merely organisational, but also have a cognitive and symbolic meaning: they have become institutionalised as academic units that define the landscape of 'what can be investigated' on human rights in a given institution. Some fields of knowledge or disciplines are prioritised over others depending on the centre to which the research structure is attached, or the area of knowledge to which it seems most natural to allocate human rights research. Although the academic community itself admits that human rights are an area of knowledge belonging to the social and legal sciences, the truth is that the researchers themselves recognise that there is not only tension between law and social and human sciences regarding central issues such as the meaning, scope and methodological approach to human rights, but that there is also friction about how human rights are conceptualised in the different disciplines under the umbrella of social sciences (Cesarini and Hertel, 2005, pp. 795-796). ${ }^{7}$

The formal organisational structures within which to carry out interdisciplinary research are understood as social constructions and spaces of opportunity for new modes of knowledge that highlight its dynamic nature and also enable its development (Weingart and Padberg, 2014). This is a necessary basis for interdisciplinarity to take place. However, such organised structures or research centres can paradoxically become the main barrier to interdisciplinarity taking place (Uribe, 2013). Even though they are decisive in its institutionalising process, they can become their main obstacle, especially

\footnotetext{
${ }^{7}$ If we look at the statements made by the main associations of these disciplines about what they understand by the term 'human rights', the differences between them are remarkable. For example, the Code of Ethics of the American Sociology Association (June 2018) frames them under the consideration of 'public good' [available at: https://www.asanet.org/sites/default/files/asa_code_of_ethics-june2018.pdf .Last accessed: 04 June 2019]. The Guide to Professional Ethics in Political Science by the American Political Science Association (2012), associates it with the term 'freedoms' [available at

http://www.apsanet.org/portals/54/Files/Publications/APSAEthicsGuide2012.pdf. Last accessed: 04 June 2019], while the Statement on Professional Ethics of the American Association of Geographers describes them as 'pursuit of well-being' [available at http://www.aag.org/cs/about_aag/governance/statement_of_professional_ethics . Last accessed: 06 April 2019].
} 
in the university field. On the one hand, formal organisational structures shape and reflect a specific classification of knowledge in certain categories that define and constitute the epistemological and methodological bases of the various disciplines. But also, on the other hand, they are determinants of the legitimisation of knowledge in a certain area. That is, they establish what may or may not be considered knowledge. Therefore, to advance the understanding of the interdisciplinary nature of academic research on human rights, we must also understand the organisational forms through which it is institutionalised, and ask whether they encourage or constrain the development of the interdisciplinary character attributed to them. Specifically, based on the results in the Spanish context, this study aims to provide an axis for the analysis of how the nature and identity of the institutional structures linked to human rights research in the university are determine the potential interaction between disciplines and, therefore, the possibility that the knowledge they generate may be really interdisciplinary.

\subsection{A brief mapping of the institutional structures for human rights research}

To analyse the possible relationship between the modes of production of knowledge about human rights and the institutional structures responsible for research at universities, the analysis carried out in 2018 and 2019 is briefly mapped out below. It is limited to the specific geographical area of Spain. ${ }^{8}$

The research centres were selected from the information collected in the main Spanish academic network in the field of human rights, The Time of Rights (Huri-Age). ${ }^{9}$ As shown in Table 1, 18 different types of university structures were analysed (institutes, chairs, observatories, laboratories and/or research groups), of which 14 are currently part of the Huri-Age network. Another four were added to this list: two institutes for human rights research at the Complutense University of Madrid and the University of Navarre, respectively; and two university chairs: one for International humanitarian law and human rights from the Institute of International and European Studies 'Francisco de Vitoria' of the Carlos III University of Madrid; and the Chair of Democracy and Human Rights of the University of Alcalá.

Research groups and projects focused on human rights were only considered for analysis if they were part of a university research structure. As noted above, the hypothesis is centred on institutionalised structures for the conduct of human rights research in universities; in other words, it revolves around centres or institutes specifically created for that purpose, which formalise and articulate their activities around research lines, projects and teams. For this reason, the study excluded some outstanding centres of

\footnotetext{
${ }^{8}$ The findings are part of a larger and more exhaustive project, scheduled to be published in 2020. It covers the analysis of university centres that conduct human rights research in Europe, North America, Latin America, Africa and Asia. The space limitations of this study have meant that findings can only be related to the Spanish context. Even so, the results of this microscopic view are very similar to those found in other contexts analysed. Therefore, despite their limitations, they provide an apt basis for discussion.

9 The network started in 2008. It is currently composed of 15 research groups and centres. For more information, see https://redtiempodelosderechos.com [Accessed: 10 May 2019].
} 
human rights research in Spain, such as the Institut de Drets Humans de Catalunya and the Instituto de Derechos Humanos Joaquín Herrera Flores in Seville, as they are both civil society organisations.

Table 1. General data of the study sample in Spain

\begin{tabular}{|c|c|c|c|}
\hline TYPE & NAME & UNIVERSITY & $\begin{array}{c}\text { YEAR } \\
\text { CREATED }\end{array}$ \\
\hline \multirow{5}{*}{ INSTITUTE } & $\begin{array}{l}\text { Instituto Universitario de Derechos } \\
\text { Humanos 'Bartolomé de las Casas' } \\
\text { ['Bartolomé de las Casas' Institute of } \\
\text { Human Rights] }\end{array}$ & $\begin{array}{l}\text { Carlos III University, } \\
\text { Madrid. }\end{array}$ & $\begin{array}{c}1990 \\
{[1993]}\end{array}$ \\
\hline & $\begin{array}{c}\text { Instituto de Derechos Humanos 'Pedro } \\
\text { Arrupe' ['Pedro Arrupe' Human Rights } \\
\text { Institute] }\end{array}$ & University of Deusto & 1997 \\
\hline & $\begin{array}{l}\text { Institut de Drets Humans } \\
\text { [Human Rights Institute] }\end{array}$ & University of Valencia & 2005 \\
\hline & $\begin{array}{l}\text { Instituto de Derechos Humanos } \\
\text { [Human Rights Institute] }\end{array}$ & $\begin{array}{l}\text { Complutense University, } \\
\text { Madrid }\end{array}$ & 1980 \\
\hline & $\begin{array}{c}\text { Instituto de Derechos Humanos } \\
\text { [Human Rights Institute] }\end{array}$ & University of Navarre & 1991 \\
\hline $\begin{array}{l}\text { RESEARCH } \\
\text { CENTRE }\end{array}$ & $\begin{array}{l}\text { Centro de Investigación de la Efectividad } \\
\text { de los Derechos Humanos [Human Rights } \\
\text { Indicators Research Center (HURIERC)] }\end{array}$ & Jaume I University & $\begin{array}{l}\text { Not } \\
\text { provided }\end{array}$ \\
\hline \multirow{3}{*}{ OBSERVATORY } & $\begin{array}{c}\text { Observatorio de Derechos Humanos } \\
\text { [Observatory of Human Rights] }\end{array}$ & University of Valladolid & 2009 \\
\hline & $\begin{array}{l}\text { Observatorio Gregorio Peces-Barba de } \\
\text { Derechos Humanos y Democracia } \\
\text { ['Gregorio Peces-Barba Observatory of } \\
\text { Democracy and Human Rights] }\end{array}$ & University of Jaén & 2013 \\
\hline & $\begin{array}{c}\text { Observatorio de Investigaciones Socio- } \\
\text { jurídicas sobre Derechos y Libertades } \\
\text { Fundamentales [Observatory of Socio- } \\
\text { Legal Research on Fundamental Rights } \\
\text { and Freedoms] }\end{array}$ & University of La Rioja & 2004 \\
\hline \multirow[b]{2}{*}{ LABORATORY } & $\begin{array}{l}\text { Laboratorio 'Sociedad de la Información y } \\
\text { Derechos Humanos' ['Information Society } \\
\text { and Human Rights' Laboratory] }\end{array}$ & University of Vigo & 2011 \\
\hline & $\begin{array}{l}\text { Laboratorio sobre la Implementación y } \\
\text { Eficacia de los Derechos Sociales - } \\
\text { Laboratorio de Sociología Jurídica } \\
\text { [Laboratory on the Implementation and } \\
\text { Effectiveness of Social Rights - Legal } \\
\text { Sociology Laboratory] }\end{array}$ & University of Zaragoza & 2002 \\
\hline \multirow{3}{*}{$\begin{array}{l}\text { RESEARCH } \\
\text { GROUPS }\end{array}$} & $\begin{array}{c}\text { Research Group, 'Informática, Lógica y } \\
\text { Derecho' . }\end{array}$ & University of Seville & $\begin{array}{c}\text { Not } \\
\text { provided }\end{array}$ \\
\hline & $\begin{array}{l}\text { Grupo de Investigación 'La Comparación } \\
\text { en Derecho Constitucional' ['Compared } \\
\text { Constitutional Law' Research Group] }\end{array}$ & University of Cádiz & $\begin{array}{l}\text { Not } \\
\text { provided }\end{array}$ \\
\hline & $\begin{array}{l}\text { Grupo de Filosofía del Derecho } \\
\text { [Philosophy of Law Group] }\end{array}$ & University of Cantabria & $\begin{array}{c}\text { Not } \\
\text { provided }\end{array}$ \\
\hline
\end{tabular}




\begin{tabular}{|c|c|c|c|}
\hline & $\begin{array}{l}\text { Grupo de Filosofía del Derecho y Filosofía } \\
\text { Política del Departamento de Derecho } \\
\text { Público [Philosophy of Law and Political } \\
\text { Philosophy Group of the Department of } \\
\text { Public Law] }\end{array}$ & $\begin{array}{l}\text { Rovira i Virgili, } \\
\text { University of Tarragona }\end{array}$ & $\begin{array}{l}\text { Not } \\
\text { provided }\end{array}$ \\
\hline \multirow[b]{2}{*}{ CHAIR } & $\begin{array}{c}\text { Cátedra de Democracia y Derechos } \\
\text { Humanos [Chair of Democracy and } \\
\text { Human Rights] }\end{array}$ & Alcalá University & 2001 \\
\hline & $\begin{array}{l}\text { Cátedra Mario Villarroel de Derecho } \\
\text { Internacional Humanitario y DD.HH. } \\
\text { ['Mario Villarroel' Chair of International } \\
\text { Humanitarian Law and Human Rights] }\end{array}$ & $\begin{array}{c}\text { Carlos III University, } \\
\text { Madrid. }\end{array}$ & $\begin{array}{l}2017- \\
2020\end{array}$ \\
\hline LEGAL CLINIC & $\begin{array}{l}\text { Clínica Legal de la Facultad de Derecho } \\
\text { [Legal Clinic of the Faculty of Law] }\end{array}$ & Alcalá University & 2012 \\
\hline
\end{tabular}

Source: Developed by the author based on public information available on these centres

In order to facilitate the analysis, the study concentrated on three axes: (a) the nature of these structures: their identity and affiliation within university architecture; (b) the characteristics of their research, teams and practice networks and relationships with academia; and (c) the impact of human rights research through the different training programmes and publications promoted by these research structures. The first axis was useful to find out who researches in these structures; the second was helpful to analyse what is investigated and how; and the third axis was used to find out for research is carried out and what its purpose is. The resulting mapping is expected to provide a basis to discuss the role that interdisciplinarity has in the research carried out in these centres. As pointed out in previous sections, this involves analysing whether the modes of production of knowledge about human rights may be determined by the structures where it is generated and, therefore, if these may trigger possible conceptual, epistemological and methodological biases.

The data were extracted from the information publicly available about these centres and was analysed using content analysis. These dimensions were combined, and the analysis was carried out based on a series of categories that assessed this correlation, as shown in Table 2:

Table 2. Categories of analysis: process of classification

\begin{tabular}{|c|c|c|}
\hline DIMENSION & CATEGORIES & CONDITIONING FACTORS \\
\hline \multirow{4}{*}{$\begin{array}{l}\text { Who conducts } \\
\text { research? }\end{array}$} & Nature & Institutionalisation of research \\
\hline & Identity & Declared identity \\
\hline & Affiliation & Connection to a discipline \\
\hline & $\begin{array}{l}\text { Predominant } \\
\text { background }\end{array}$ & Connected disciplines \\
\hline \multirow{4}{*}{$\begin{array}{l}\text { What is } \\
\text { researched and } \\
\text { how? }\end{array}$} & Lines & Connection to knowledge areas \\
\hline & Team & Affiliation to a field of knowledge \\
\hline & Publications & Practice network \\
\hline & Projects & Practice network \\
\hline
\end{tabular}


KNOWLEdge Production Methods In Human Rights RESEARCH:

CONSTRAINTS AND OPPORTUNITIES FOR THE PROMOTION OF AN INTERDISCIPLINARY APPROACH

\begin{tabular}{|c|l|l|}
\hline \begin{tabular}{c} 
For whom is $\begin{array}{c}\text { research } \\
\text { conducted? What } \\
\text { is its purpose? }\end{array}$ \\
\cline { 2 - 3 }
\end{tabular} & $\begin{array}{l}\text { Educational } \\
\text { programmes }\end{array}$ & Enhancement of educational capabilities \\
\hline
\end{tabular}

Source: Developed by the author

The types of the 18 structures analysed and their reported activities were compared to outline the initial mapping: out of all of them, the three university research institutes from the Carlos III University of Madrid, the University of Deusto and the University of Valencia had the highest level of institutionalisation in the structure of their respective university institutions. This contrasted with those of the Complutense University of Madrid and the University of Navarre, which, despite being the oldest, based on the information publicly available, reflected a low level of research activity. The Complutense University of Madrid focuses its activity on its publication entitled Yearbook of Human Rights and its own titles on human rights, which have been published since the 1980/1981 academic year. ${ }^{10}$ There was very little information publicly available on the University of Navarre. The only useful data that could have been taken into account in the study were the year when it was founded (1991) and its type and affiliation: the area of Philosophy of Law, attached to the Faculty of Law of the University of Navarre. ${ }^{11}$ The remaining organisational structures had different denominations but were all initiatives mainly driven by research teams. Most of them (particularly those included in the Huri-Age network) were found to be well-established, stable groups with a track record recognised both nationally and internationally.

Looking at these ways of institutionalising human rights research in Spanish universities, it can be concluded that they have been consistent with the traditional formal organisation of research in academia, through the creation and consolidation of research groups who work in a stable manner, mainly linked to specific structures for the development of R\&D\&i, such as university research institutes, research centres and/or other academic structures. Their main objectives are: to promote certain lines of research on human rights; to allocate teaching and research staff to them to carry it out; to promote specialist postgraduate training at Master's and PhD levels; and to foster the dissemination and transfer of the knowledge generated to society.

These organisational structures are a very visible component of the disciplinary organisation in the university context. While in the field of human rights borders between disciplines may be disputed, they mark not only certain organisational, but also cognitive, jurisdictions (Gumport and Snydman, 2002, p. 378). The institutionalisation of knowledge in these structures helps define what is understood as being knowledge in a given area of research. It also allows this knowledge to be showcased and recognised as specifically human rights research, at least with respect to those other initiatives which, may deal with related issues but are not explicitly aimed at human rights.

\footnotetext{
${ }^{10}$ For more information see: https://www.ucm.es/idh [Accessed: 10 May 2019].

11 For more information see: https://www.unav.edu/web/facultad-de-derecho / research-institutes [Accessed: 10 May 2019].
} 
The average age of the research structures included in the study was 16 years. Nearly all of them were created at the end of the twentieth century or at the beginning of the twenty-first century. This does not mean that human rights had not been the object of interest in Spanish university research until then; ${ }^{12}$ or that the central topics related to its study had not been established. However, it was only in the 1960s that the concept of 'human rights' began to be used in Spain, 'although somewhat problematically' (Rivaya, 2009, p. 572), and that a specific human rights doctrine was built from a liberal and democratic worldview. ${ }^{13}$ From the 1980 s, the study on human rights became part of the Philosophy of Law. This gave rise to a number of emblematic publications that contributed significantly to its dissemination. In 1984 the publication of the Anuario de Filosofia del Derecho (linked to the Spanish Society of Legal and Political Philosophy) was resumed, and the journal Doxa, Cuadernos de Filosofía del Derecho, directed by Manuel Atienza from the University of Alicante, was first published. Since then, as Rivaya pointed out, nearly every philosopher of law in Spain has written about human rights (Rivaya, 2009, p. 577). During this time, the Complutense University of Madrid established the first university centre dedicated to the research, teaching and dissemination of human rights (1980), founded by Gregorio Peces-Barba. The same academic year saw the start of the first specialist course in human rights, directed by Joaquín Ruiz-Giménez.

The year 1980, therefore, can be considered to be the starting point for the establishment of a gradual process of human rights research institutionalisation in Spanish universities, built around a series of academic structures that brought together the legacy of a long tradition that would serve as the basis for further development. A decade later, the 'Bartolomé de las Casas' Institute of Human Rights emerged at Carlos III University, Madrid, which published the Derechos y Libertades journal, initially directed by PecesBarba. In 1997, the 'Pedro Arrupe' Institute of Human Rights was founded at the University of Deusto. The rest would progressively be set up from 2000 onwards.

\section{a) Type, identity and affiliation}

The above account points to an interesting axis for analysis. Institutionalisation has been strongly determined by how Human Rights research was initiated in Spain. Some studies were undertaken by researchers from the area of Public International Law, and most of them by researchers from the area of Philosophy of Law, both jurists and philosophers. ${ }^{14}$ The area of legal research was clearly predominant. For this reason, the analysis of the nature of these organisational structures is consistent with the obvious and

\footnotetext{
${ }^{12}$ For a further understanding of the thinking about human rights in Spain, the work of García Manrique (1996) and Rivaya (2009 and 2010), among others, provided a particularly detailed analysis of the different human rights doctrines in the twentieth century, specifically during the Francoist period.

13 The works by the members of the so-called 'Ruiz-Giménez School', including Elías Díaz, have been recognised as being representative of how the theme of human rights was introduced in philosophy of law in Spain. The publication of Derechos Fundamentales by Gregorio Peces-Barba in 1973 began a doctrine that would be continued by a large school until today (Rivaya, 2009, p. 569).
} 
problematic manner in which human rights research began and later became established within the university environment.

Fourteen academic structures are affiliated to the Faculty of Law of their respective Universities. The 'Bartolome de las Casas' Institute of the Carlos III University, Madrid is affiliated to the Faculty of Social Sciences and Legal Sciences. It was founded in 1990. The Institute was set up by Peces-Barba after the activities and the core of the teaching staff of the Institute of Human Rights from the Complutense University of Madrid were transferred in 1989. Research within this Institute has taken place since then in different disciplines of Law. For its part, the 'Pedro Arrupe' Institute of Human Rights was established in 2009 in the Faculty of Social and Human Sciences of the University of Deusto, as a result of the restructuring of several centres brought about by the Bologna Reform, among other things. It was created and managed by Jaime Oraá (Professor of Public International Law) 12 years ago as part of the Faculty of Law of that university. Some $61.5 \%$ of the researchers who are currently part of its team come from the Law area. It has now become an interdisciplinary institute, interdependent of both the Social and Human Sciences and the Law. This change of affiliation has not had any negative repercussions as to its initial legal background; rather, it has meant that the Institute has been able to maintain it.

The creation of university faculties is associated with the specialisation of knowledge and its institutionalisation within the academic structure of the university. The areas of knowledge are always the fundamental grounds for a university's institutional organisation (Clark, 1983: 41). For human rights, as can be seen from the institutional outline provided, these appear related and attached to the area of Law and the different disciplines into which it is organised. This also accounts for the institutional place from which the challenges and needs that have emerged in the Spanish academia regarding human rights have been hegemonically addressed.

Zooming in further to look at the disciplines of Law that have been engaged in human rights research, the main areas are the Philosophy of Law, Public International Law, Legal Sociology and Constitutional Law. Except for the 'Mario Villarroel' Chair in Humanitarian International Law and Human Rights, attached to the Francisco de Vitoria Institute for International and European Studies of the Carlos III University, Madrid, and the 'Pedro Arrupe' Institute of Human Rights at the University of Deusto, the rest of the structures are either affiliated to or mostly composed of researchers from the departments of Philosophy of Law. This makes it the main discipline that holds together University-based institutional research on human rights in Spain.

While there are some different nuances, all of the institutions outlined share a common research objective and seek to meet the challenges that human rights presently pose in our societies and the need to make progress in building a culture of human rights. The lines of research established by the Huri-Age network, which brings together the 
most active centres, also have that objective at heart. ${ }^{15}$ In general, there is a more or less explicit recognition ${ }^{16}$ of the multidisciplinary nature of the research carried out, although there is a dominant influence of Law and, specifically, of Philosophy of Law.

This characterisation of the inter/multidisciplinary nature of human rights research carried out in these structures has a significant connotation. It points to the selfunderstanding of an area of knowledge that is intrinsically heterogeneous. This identity feature is the result of the opening and crossing of borders held by the different Law disciplines with others such as Political Philosophy, International Relations, Political Science, Sociology and Anthropology. However, since the status of that human rights research in university structures that have contributed to its institutionalisation and legitimisation is so entrenched, a question arises: is interdisciplinarity possible? If so, how successful has that conceptual, epistemological and/or methodological interaction with other disciplines been, and what was its purpose (to ensure that the result was an interdisciplinary study)?

\section{b) Characteristics of the research conducted. Research teams}

The recognition of the interdisciplinary nature of human rights research runs the risk of becoming merely rhetorical; of being compulsorily accounted for in theory, but completely removed from the demands that make it possible in actual practice. This is a critical issue that makes it necessary to probe further into the features of this institutionalisation, by looking at the objectives, modes of production and the results of this type of research.

The map obtained from the analysis of the nature and affiliation of human rights research within the university architecture shows a rather predictable profile of the research groups. This is a long way from the rationale of knowledge construction that is a characteristic of interdisciplinarity. In fact, this confirms the importance of the organisation of disciplines and the impact it has on the modes of knowledge production. They are research structures that render some conceptual, epistemological and methodological features, and the rationales and inertia inherent in this type of research hegemonic. Not only do the majority of human rights researchers come from the field of Law; the majority come from the Philosophy of Law and Public International Law. Both have the greatest number of research staff in these structures. This information is relevant because it has direct implications for the leadership of the research projects carried out by these teams, among other things.

15 See https://redtiempodelosderechos.com/descripcion-2/lineas-de-investigacion/ [Accessed: 12 May 2019].

${ }^{16}$ See, for example, the definition of the Institute of Human Rights of the University of Valencia (available at: http://www.idhuv.es/ ); the Human Rights Observatory of the University of Valladolid (available at: http://odh.uva.es/quienes-somos/); the Observatory of the University of La Rioja (available at: https://investigacion.unirioja.es/groups/15/lineas ); or the Chair of Democracy and Human Rights of the University of Alcalá (available at http://www3.uah.es/catedra_ddhh/inicio .html ) [Accessed: 12 June2019]. 
In the 2018-2019 period, funding was granted to nine active competitive projects that submitted bids to the major calls for R\&D\&i proposals in Spain. Some of the research groups involved are included in the sample. In five of them the principal researchers were from the area of Philosophy of Law, three were led by researchers from the area of Public International Law; and only one of them, completed in 2018, was directed by a researcher from the area of Sociology. Therefore, the area of knowledge to which these projects were mostly affiliated and where they were recognised by public research support institutions was that of the Legal Sciences, regardless of whether the sub-discipline of 'human rights' was integrated into the branch of Political Sociology and the area of Political Science. Financing institutions awarded a greater proportion of funding to human rights research projects that were submitted by researchers in the area of legal sciences. This means that the relationship between a specific disciplinary area and a given research object becomes strengthened and ultimately naturalised, as is the case of Philosophy of Law and Public International Law with human rights.

Additionally, the recurrence of the principal researchers in projects prior to 2018 was analysed. A tendency was identified to maintain the leadership of the principal researchers in the projects, with little or no turnover. The original discipline of the majority of researchers in the research/work teams for these projects was the same as that of the principal researcher. The network of relationships, therefore, was also limited to the discipline that predominated in the project profile. The consequence was a relative homogenisation of research topics on human rights, which was also reflected in the themes of the publications by researchers affiliated to these structures.

The labels used for the lines of research promoted by these institutional structures was found to be striking. Their nomenclature was consistent with fundamental challenges currently linked to human rights, such as human mobility, conflicts and borders, discrimination, complex inequalities, exercise of rights, inclusive citizenship and the transformation of justice, to name a few. The Huri-Age network itself emerged with the objective of 'analysing the situation of Human Rights in contemporary societies by using a comprehensive approach, identifying the main challenges and problems they currently face and may face in the future, and propose possible solutions that lead to achieving an International Rule of Law'. ${ }^{17}$ However, it should be clarified that the research carried out by these teams is effectively aimed at meet these challenges, with the objective of addressing any potential gaps, problems resolved by other areas of law or deficiencies in the study of human rights in the Spanish scholarly context from a legal perspective. It is based on the recognition that the Law is not exhausted in the mere formal-normative analysis of current positive law. It is also an unquestionable political, moral, social, cultural and historical reality (Rivaya, 2009, p. 87). Disciplines such as the Philosophy of Law contribute to providing a critical approach or finding solutions to problems that are unresolved or yet to be finetuned in legal research. While they do not do so in isolation, but through dialogue with other research areas outside the legal sciences, their function is to reflect on problems from within the legal experience.

${ }^{17}$ See http://www.tiempodelosderechos.es/es/descripcion.html [Accessed: 12 May 2019]. 
Obviously, human rights are not the only theme studied by these Law disciplines; however, as this area has become part of their endeavour, and it has been recognised that their study requires the creation of stable research structures, the area of human rights has come to share the characteristics that define and articulate legal research. Its specific function within all these structures seems to be to reflect on human rights from within the legal experience. The human rights research approved and supported by the main research regional agencies in Spain prioritises more comprehensive approaches consistent with these human rights research structures. While mixed methodological approaches predominated in the projects analysed, most of them were focused on legal science methodology. This is another sign of the specialised modes of knowledge production to which human rights research is subject. Based on this consideration, how can its interdisciplinary character be understood?

\section{c) Enhancement of educational and dissemination capabilities}

One way -but not the only way- of confirming this possible process of epistemological and methodological specialisation in human rights research is to contrast the results of subsequent analyses with the training capacity of researchers affiliated to the stable structures that have been part of the sample. The PhD theses completed and the articles derived from them use the specific literature from the areas of Law that have traditionally been dedicated to human rights research almost exclusively. The results are published in journals or publishers promoted by the same university institutions.

Doctoral programmes do not include among their educational activities any specialisation courses specific to human rights methodology or interdisciplinary research methodology. Most of the courses and reading lists on human rights research methodology offer collected techniques from a single discipline aimed at students from associated disciplines: a compendium of sources or database search engines; basic training in the research career and the skills required; legal research methods for Law students; social sciences methodologies (mainly for sociology and anthropology) for the rest of the students. Largely descriptive information is often used obtained from different international instruments, treaties, legal norms, principles, judgments and specific cases.

Although research seminars are firmly promoted, no spaces were found among those consulted for assessing or discussing different methodological options, or techniques to combine them. Nor were tools provided to enable non-specialists in a given area to benefit from the epistemological and methodological potential of other disciplines. The strong educational capacity of these structures (as they host the main postgraduate programmes at the Master's and PhD levels in Spain in the field of human rights) is built only on the epistemological and methodological grounds provided by each discipline, which very often corresponds to the legal area.

These human rights research structures also stand out because they are responsible for the main scientific and editorial publications on human rights in Spain: the Institute of Human Rights of the University of Valencia publishes Cuadernos Electrónicos de Filosofía del Derecho; The 'Bartolome de las Casas' Institute of la Carlos III University 
in Madrid publishes the Derechos y Libertades journal; the 'Pedro Arrupe' Institute of Human Rights from the University of Deusto publishes the Deusto Journal of Human Rights; and The Age of Human Rights Journal, a scientific journal published in English within the Huri-Age Research Network, to which the most important human rights research groups in Spain belong, as noted on its public website. A very significant number of researchers attached to these structures actively participate, either as authors or as part of the editorial board and/or as advisors, in the Anuario de Filosofía del Derecho, and also, although to a lesser extent, in the Revista Española de Derecho Internacional and the Revista Española de Derecho Constitucional. ${ }^{18}$ They also have close links to Spanish publishers (for example, Tirant lo Blanch, Dykinson, Aranzadi o the collections of the publishing house of the Centro de Estudios Politicos y Constitucionales), which occupy the top positions in the prestige and quality rankings according to academic experts. ${ }^{19}$

\section{LIMITATIONS AND OPPORTUNITIES FOR THE PROMOTION OF AN INTERDISCIPLINARY APPROACH IN HUMAN RIGHTS RESEARCH}

This brief mapping has shown some of the features of human rights research conducted by academic structures in the Spanish context. The results show that human rights research is becoming well-established in Spanish universities, strengthened by the recognition (since 2007) of a network of research excellence and the existence of a wellestablished universe of formal structures, at least 16 of those analysed, which have allowed for their institutionalisation. All this has been further strengthened by the membership of some of them to a global network of human rights researchers, gathered around the Association of Human Rights Institutes [AHRI], ${ }^{20}$ and currently led by the Danish Human Rights Institute.

Obviously, this consolidation process has been possible because of a series of, not only disciplinary, but also very specific socio-political circumstances in Spain, which has strongly determined the reception and subsequent conduct of studies on human rights. All this has gradually resulted in a focused space for research on human rights that has been institutionalised into academia around a series of formal and stable structures. The features of these structures have conditioned the ways of producing knowledge about human rights in Spain, which have caused the different branches of the legal sciences to

\footnotetext{
${ }^{18}$ See also Cuadernos electrónicos de Filosofía del Derecho: https://ojs.uv.es/index.php/cefd; Derechos y Libertades https://www.uc3m.es/investigacion/derechos-libertades; Deusto Journal of Human Rights http://revista-derechoshumanos.revistas.deusto.es/; Age of Human Rights Journal: https://revistaselectronicas.ujaen.es/index.php/TAHRJ; Anuario https://www.filosofiadelderecho.org/publicaciones/anuario-de-filosofia-del-derecho-2/; Revista Española de Derecho Internacional: http://www.revista-redi.es/es/lineas-de-investigacion/; Revista Española de Derecho Constitucional: http://www.cepc.gob.es/publicaciones/revistas/revistaselectronicas?IDR=6 [Accessed: 14 June2019].

${ }^{19}$ See the 2018 ranking of law publishers published by Scholarly Publishers Indicators in Humanities and Social Sciences, a benchmark for the evaluation of the quality of Spanish publishers: http://ilia.cchs.csic.es/SPI/prestigio_sectores_2018_2.php?materia=Derecho\&tabla_esp=spi_editoriales_d erecho\&tabla_extr=spi_editoriales_derecho_extr [Accessed: 14 June 2019].

${ }^{20}$ See at https://www.humanrights.dk/ research-project / association-human-rights-institutes-ahri-globalnetwork-human-rights-researchers [Accessed: 14 June 2019].
} 
play a central role. There is more university research on human rights in Spain being carried out by other research centres and groups, but the importance of those analysed in this study is indisputable. They have had the opportunity of becoming formalised in stable structures in the university architecture, which has been decisive in understanding the place and recognition that it enjoys today.

This study has analysed the modes of production of institutional research on human rights and assessed its widely recognised interdisciplinary nature. The analysis provided a brief outline that has helped to make the importance of the legal disciplines (nature, identity, objectives, approach, projects, procedures and training focus) visible. This has shown the emphasis on the research rationales of these structures and their correlation with the recognition they receive from public research support bodies. The findings have identified different types of institutionalisation of human rights research in Spanish universities, and have confirmed the pre-eminence of its affiliation to the Faculties of Law and a close connection with those Departments that contain this object of study: mainly Philosophy of Law, Public International Law and Constitutional Law. The series of consequences this has for the organisation and production of knowledge in these structures has been reported.

The underlying question for this study was whether these organisational and academic structures of knowledge about human rights make interdisciplinarity possible. The results show that the bases on which they have been built do not make it possible. In addition, the inertia inherent in the research system established in the Spanish context does not encourage it. The indicators that evaluate the multidisciplinary nature of the projects only take into account the incorporation of researchers from different disciplines; however, it does not include indicators to evaluate the quality of the epistemic and methodological interaction between them. In the academic framework, there is little academic culture to understand interdisciplinary approaches and to establish stable working relationships. The interdisciplinary structures are weak and hinder the development of the academic careers of the researchers attached to them. The path to interdisciplinary research seems to be too rocky.

Undoubtedly, there are internal and external conditions that limit the development of interdisciplinary research. However, human rights research needs interaction between disciplines to be more effective. Unless some movement is made in this direction (which is by no means easy), the modes of production of knowledge in this area will be conceptually, epistemologically and methodologically biased. Their answers will be unable to effectively solve the theoretical and practical problems that human rights need. 


\section{REFERENCES}

Apostel, L., Berger, G., Briggs, A., and Michaud, G. (1972). Interdisciplinarity problems of teaching and research in universities. Washington: OECD Publications Center.

Barry, A.; Born, G. and Weszkalnys, G. (2008). Logics of interdisciplinarity. Economy and Society 37(1), pp. 20-49. https://doi.org/10.1080/03085140701760841

Bobbio, N. (1990). Naturaleza y función de la filosofía del Derecho. In: ID. Contribución a la Teoría del Derecho. Madrid: Debate.

Bobbio, N. (1991). Sobre el fundamento de los derechos del hombre. In: ID. El tiempo de los derechos (Translation by Rafael de Asis Roig). Madrid: Sistema.

Brown, W. (1995). States of Injury: Power and Freedom in Late Modernity. Princenton: Princenton University.

Brown, W. and Halley, J. (2002). Left Legalism /Left Critique. Durham: Duke University Press. https://doi.org/10.1215/9780822383871

Cesarini, P. and Hertel, S. (2005). Interdisciplinary Approaches to Human Rights Scholarship in Latin America. Journal of Latin American Studies, 37(4), pp. 793809. https://doi.org/10.1017/S0022216X05009879

Chandramohan, B. and Fallows, S. (eds.) (2009). Interdisciplinary learning and teaching in higher education. New York: Routledge. https://doi.org/10.4324/9780203928707

Clark R.B. (1983). The higher education system. Academic organization in cross-national perspective. Berkeley, LA: University of California Press.

Claude, R. P. (2002). Science in the service of human rights. Philadelphia: University of Pensylvania Press.

Del Real, J.A. (2011). La identidad de la Filosofía del Derecho como materia útil para juristas, Anuario de Filosofía del Derecho, 27, pp. 83-110.

Donnelly, J. (2003). Universal Human Rights in theory and practice. Ithaca: Cornell University Press.

Downing, T.E. and Kushner, G. (eds) (1988). Human Rights and Antropology. Cambridge: Cultural Survival.

European Commission (2015). Quests for interdisciplinarity: A challenge for the ERA and HORIZON 2020 Policy Brief by the Research, Innovation, and Science Policy Experts (RISE). Available at:

https://ec.europa.eu/research/openvision/pdf/rise/allmendingerinterdisciplinarity.pdf [Accessed: 01-06-2019].

Forsythe, D. P. (2017). Hard Times for Human Rights. Journal of Human Rights 16(2), pp. 242-253. https://doi.org/10.1080/14754835.2017.1313698

Freeman, M. (2011). Human Rights: an interdisciplinary approach, $2^{\text {nd }}$ ed., Cambridge (UK): Polity Pres. 
Frodeman R., Klein J. T., and Mitcham, C. (2010). Oxford Handbook of Interdisciplinarity. Nueva York: Oxford University Press.

Frodeman, R. (2014). The end of disciplinarity. In: Weingart, P. and Padberg B. (eds.), University experiments in interdisciplinarity. Obstacles and opportunities. Bielefeld: Transcript, Science Studies, pp. 175-198. https://doi.org/10.14361/transcript.9783839426166.175

García Manrique, R. (1996). La filosofía de los derechos humanos durante el franquismo, Madrid: Centro de Estudios Constitucionales.

Geertz, C. (1980). Blurred genres: the refiguration of social thought, American Scholar, 42(2), pp. 165-179.

Gewirth, A. (1984). The Epistemology of Human Rights. Social Philosophy and Policy, 1(2), pp. 1-24. doi: 10.1017/S0265052500003836. [Accessed: 07-08-2019].

Gibbons, M., Limoges, C., Nowotny, H., Schwartzman, S., Scott P. and Trow, M. (2010). The New Production of Knowledge. The dynamics of science and research in contemporary societies. London: Sage Publications. doi: 10.4135/9781446221853 [Accessed: 07-08-2019].

Greenhill, B. (2015). Transmitting Rights. New York, NY: Oxford University Press.

Gordon, E. T. (1991). Antropology and Liberation. In: Harrsison, F, (ed.) Decolonizing antropology: Moving further toward an antropology for liberation. Washington D.C.: Association of Black Antropologists.

Gumport, P., and Snydman, S. (2002). The formal organization of knowledge: an analysis of academic structure. The Journal of Higher Education, 73(3), 375-408. https://doi.org/10.1080/00221546.2002.11777153

Hafner-Burton E. M. (2013). Making Human Rights a Reality. Princeton, NJ: Princeton University Press. https://doi.org/10.23943/princeton/9780691155357.001.0001

Haight W.L. and Bidwell, L. N. (2016). Mixed methods research for social work: integrating methodologies to strengthen practice and policy. Chicago, Illinois: Lyceum Books, Inc.

Haraway, D. (1988). Situated Knowledge: the science question in feminist as a site of discourse on the privilege of partial perspective. Feminist Studies 14(3), pp. 575599. https://doi.org/10.2307/3178066

Harrison, M. (2005). 'Reflexiones sobre el estudio de los derechos humanos y su fundamentación', Universitas. Revista de Filosofía, Derecho y Política, 2, pp. 1336.

Hirsch-Hadorn, G.; Hoffmann-Riem, H.; Biber-Klemm, S.; Grossenbacher-Mansuy, W.; Joye, D.; Pohl, C.; Wiesmann, U. and Zemp, E. (eds.) (2008). Handbook of transdisciplinary research. New York: Springer. https://doi.org/10.1007/978-1-4020-6699-3

Holley, K. A. (2009). Understanding interdisciplinary challenges and opportunities in Higher Education. San Francisco: Jossey Bass. 
Huutoniemi, K.; Klein, J. T.; Brunn, H. and Hukkinen, J. (2010). Analyzing interdisciplinary: typology and indicators. Research Policy, 39, pp. 79-88. https://doi.org/10.1016/j.respol.2009.09.011

Ignatieff, M. (2001). Human Rights as politics and idolatry. Princenton: Princenton University Press. https://doi.org/10.1515/9781400842841

Jacobs, J.A. and Frickel, S. (2009). Interdisciplinary: A critical assessment. Annual Review of Sociology, 35, pp. 43-65.

https://doi.org/10.1146/annurev-soc-070308-115954

Klein, J.T. (1990). Interdisciplinary: History, Theory, and Practice. Wayne State University Press, Detroit.

Klein, J. T. (2008). Evaluating of interdisciplinary and transdisciplinary research. A literatura review. American Journal of Medicine, 35(2S), pp.116-123. https://doi.org/10.1016/j.amepre.2008.05.010

Klein, J.T. (2010a). 'A taxonomy of interdisciplinarity'. In Frodeman R., Klein J. T. and Mitcham, C. Oxford Handbook of Interdisciplinarity. Nueva York: Oxford University Press, pp. 15-30.

Klein, J.T. (2010b). Creating Interdisciplinary Campus Cultures. San Francisco: JosseyBass.

Langford, M. (2016). Interdisciplinarity and Multimethod Research, University of Oslo Faculty of Law Research Paper no. 2016-30.

Lattuca, L.R. (2001). Creating interdisciplinarity. Interdisciplinary research and teaching among College and University Faculty. Nashville: Vanderbilt University Press.

Messer, E. (1993). 'Antropology and Human Rights', in Annual Review of Antropology, 221, pp. 224-255. https://doi.org/10.1146/annurev.anthro.22.1.221

Moyn, S. (2010). The last utopia: human rights in history. Cambridge, MA: The Belknap Press of the Harvard University Press.

Peces-Barba, G., (1973). Derechos fundamentales. I. Teoría General, Madrid: Guadiana.

Repko, A. and Szostak, R. (eds.) (2017). Interdisciplinary Research: process and theory. $3^{\text {rd }}$ ed. Thousands Oaks, CA: Sage Publications. https://doi.org/10.4135/9781483349541

Repko, A., Newell, W. and Szostak, R. (eds.) (2011). Case studies in interdisciplinary research. Thousands Oaks, CA: Sage Publications.

Rivaya, B. (2009). 'Historia política de la filosofía del Derecho española del siglo xx, DOXA, Cuadernos de Filosofía del Derecho, 32, pp. 541-582. Available at: https://rua.ua.es/dspace/bitstream/10045/20382/1/DOXA_32_22.pdf [Accessed: 23-05-2019].

Rivaya, B. (2010). Una historia de la Filosofía del Derecho española del siglo XX, Madrid, Iustel. 
Spivak, G. (1988). Can the subaltern spreak? In: Nelson, C y Grossberg, L. (eds). Marxism and the interpretation of culture. Chicago: University of Illinois Press.

Uribe, C. (ed.) (2013). La interdisciplinariedad en la universidad contemporánea. Reflexiones y estudios de caso. Bogotá, Colombia: Pontificia Universidad Javeriana.

Vincent, R. J. (1986). Human Rights and International Relations. Cambridge (UK): Cambridge University Press.

Weingart, P. and Padberg, B. (eds) (2014). University experiments in interdisciplinarity. Obstacles and opportunities. Bielefeld: Transcript, Science Studies. https://doi.org/10.14361/transcript.9783839426166

Ziman, J. (2000). Real Science. What it is, and what it means, Cambridge, UK: Cambridge University Press. https://doi.org/10.1017/CBO9780511541391

Received: September $25^{\text {th }} 2019$

Accepted: October $28^{\text {th }} 2019$ 